\title{
Determinants of managerial behaviour in the Tunisian banking industry
}

\author{
ZAGHLA Abdessalem ${ }^{1}$, BOUJELBENE Younes ${ }^{2}$ \\ ${ }^{1}$ Finance at the Higher Institute of Business Administration of Sfax \\ ${ }^{2}$ Quantitative Methods and Director of the Higher Institute of Business Administration of Sfax
}

\section{Email address:}

zaghla1979@gmail.com(Z. Abdessalem)

\section{To cite this article:}

ZAGHLA Abdessalem, BOUJELBENE Younes. Determinants of Managerial Behaviour in the Tunisian Banking Industry. International Journal of Economics, Finance and Management Sciences. Vol. 1, No. 6, 2013, pp. 335-346. doi: 10.11648/j.ijefm.20130106.21

\begin{abstract}
This paper determines management behaviour for Tunisian banking industry between 1989 and 2006 . Following the Granger causality, we examine the intertemporal relationships between bank efficiency, loan loss provision and capitalisation. The possible relationships between the variables imply different modes of management behaviour namely bad management, bad luck, skimping, and moral hazard behaviour. We extend the Granger causality model developed by Berger and DeYoung (1997) by applying G.M.M dynamic panel estimators on a panel of Tunisian commercial banks. The econometric results suggest that the intertemporal relationships between the loan loss provision and productive efficiency are checked in only one direction. Our data provide evidence for the bad luck hypothesis suggesting the exogeneity of bad loans triggering inefficiency. In addition, we find no evidence of bad management hypothesis for the Tunisian commercial banks. Thus, these banks adopted a skimping behaviour over 1989-2006 period. Finally, the moral hazard behaviour, according to which the managers of the thinly capitalised banks assume additional portfolio risk, was identified in the context of the Tunisian banks.
\end{abstract}

Keywords: Cost/Profit Efficiency, Granger Causality, Stochastic Frontier Analysis, Managerial Behaviour

In competitive markets, environmental pressures such as bank regulations and the organisational structures of markets and firms condition the response and effort of management towards improving efficiency (Button and Weyman-Jones, 1992). Differences in bank organizational structures, for instance, in terms of their ownership might explain variations in inefficiencies because of principal agent problems that offset the conditioning effect that environmental pressure brings to bear on managerial effort. This is an empirical issue, which has received considerable attention in the bank efficiency literature albeit yielding somewhat mixed or inconclusive results (see Cebenoyan and al., 1993; Berger and Humphrey, 1997; Altunbas and al., 2001; Hasan and Marton, 2003; Weill, 2004; Bonin and al., 2005; Fries and Taci, 2005).

One limitation of the bank ownership-efficiency literature is that, in general, it simply determines whether banks organised under one ownership model are significantly more efficient than banks organised in another way. Whilst this literature is informative for bank regulators and policy makers especially when subsequent analyses quantifies the differences in the characteristics of efficient and inefficient banks, it says little about management behaviour.

As a complement to those studies that differentiate efficiency levels between ownership models, there is a smaller literature that relates aspects of bank management with efficiency. For instance, DeYoung and al. (2001) have studied the management structure of small US banks finding that management behaviour is aligned with shareholder interests through incentive and monitoring procedures at the most profit efficient banks. Managerial prudence in terms of a higher level of bank capitalisation has been found to be positively related to earnings (expected bankruptcy costs hypothesis) and efficiency (moral hazard hypothesis) (Berger, 1995; Mester, 1996), respectively. These findings are particularly relevant in the light of current regulatory discussions as to what constitutes the optimal amount of bank capital.

A different approach to understanding management behaviour considers the intertemporal relationships between productive efficiency, problem loans, capitalisation, and credit risk (see Berger and DeYoung, 1997; Williams 2004; Rossi and al. 2005; Weill and al. 
2008). The signing and direction of these intertemporal relationships is construed as evidence of specific types of management behaviour, namely bad management, bad luck, skimping and moral hazard behaviour. Granger causality methods show the intertemporal ordering of the variables and can identify which type of management behaviour exists although it is noted that management behaviour is not mutually exclusive and it is possible that banks may display characteristics of more than one behavioural type.

To best of our knowledge the literature on the managerial behaviour and productive efficiency is not applied to the context of the Tunisian banking industry. Our aim in this paper is to provide empirical evidence on this issue by checking the link between managerial behaviour and efficiency of banks.

We use an exhaustive dataset for Tunisian banks from 1989 to 2006, which avoids any sample selection bias and any bias resulting from the adoption of proxy variables. We extend the Granger causality framework used by Berger and DeYoung (1997) and Williams (2004) by applying generalized method of moments G.M.M dynamic panel estimators (Arellano and Bond, 1991; Arellano and Bover, 1995). These estimators are specifically designed to address the econometric problems induced by unobserved bankspecific effects and joint endogeneity of the explanatory variables in lagged-dependent variable models such as the one adopted to test Granger causality.

The structure of the paper is as follows. Section 1 presents the empirical background and main hypotheses. The methodology is described in Section 2. Section 3 develops the empirical results. Finally, we provide some concluding remarks in Section 4.

\section{Background}

\subsection{Main Hypotheses of Management Behaviour}

Four modes of management behaviour have been identified by Berger and DeYoung (1997) ${ }^{1}$. They are so called bad management, bad luck, skimping behaviour, and moral hazard behaviour. Each behavioural mode may be identified through the intertemporal ordering of the relationships between loan loss provision, efficiency, and capitalisation. Whilst Berger and DeYoung used the amount of problem loans as their indicator of asset quality, we have selected loan loss provision as our indicator because of data limitations. The discussion below outlines each of the management hypotheses and the expected relationships between the variables.

Bad management hypothesis implies that low productive efficiency Granger-causes larger amounts of loan loss provision (implying deteriorating asset quality) because management fails to control operating costs, which

\footnotetext{
${ }^{1}$ The same approach has been used by Williams (2004) using a sample of European savings banks; Rossi et al. (2005) for the banking sectors of Central Europe and Eastern European Countries and Weill et al. (2008) for the Czech banks.
}

immediately realises low cost efficiency suggesting that poor managerial practice causes an increase in loan loss provision after a lag. In badly managed banks, low levels of productive efficiency signal poor senior management quality. Poor managers do not adequately control or monitor operating expenses and loan portfolio management is weak. Specifically, so-called bad managers exhibit the following tendencies. They are not adept at credit scoring and select a relatively high proportion of investments with low or negative net present values; collateral is improperly valued; and customers are not sufficiently monitored in order to ensure compliance with the loan contract.

Managers that engage in skimping behaviour reduce the amount of bank resources that are expended on monitoring and underwriting lending business. The outcome affects the quality of loans and the level of productive efficiency because bank managers face a trade-off between short-term operating costs and future loan quality. The decision facing management is should they minimise short term operating costs through reducing expenditure on monitoring borrowers in an attempt to enhance long term profitability.

Therefore, management postpones dealing with deteriorating asset quality until an unspecified future date. Skimping behaviour gives the misleading impression that banks are efficient in the short-term because fewer resources are supporting the same quantity of output, which suggests that the amount of loan loss provision will increase over time. The skimping hypothesis predicts an expected positive relationship between cost efficiency and loan loss provision with the former Granger-causing increases in the latter.

The difference between bad management and skimping is that Granger causality from cost efficiency to loan loss provision is negative for the former hypothesis and positive for the latter. Following a recommendation by Berger and DeYoung (1997), we re-test for skimping behaviour using estimated alternative profit efficiency as the measure of bank efficiency in place of estimated cost efficiency.

According to the bad luck hypothesis, exogenous events increase loan loss provision (reducing asset quality) that Granger causes a decrease in cost efficiency. As a consequence, management must allocate additional resources including greater managerial effort to deal with this adverse situation, which in turn raises operating costs. Operating costs could increase for several reasons; monitoring delinquent borrowers and valuing collateral; if default occurs, seizing, storing and disposing of collateral; maintaining the bank's record on safety and soundness to regulators and market participants; allocating extra resources to protect the quality of existing loans; and diverting senior management away from their daily responsibilities.

Whereas bad luck has the opposite temporal ordering to bad management, both hypotheses predict that loan loss provision is negatively correlated with productive efficiency.

Moral hazard behaviour suggests that managers of thinly 
capitalised banks are less risk averse because the upside risk of low capitalisation outweighs the downside risk. In other words, expected return is positively related to the amount of risk assumed by bank management whilst the bank has relatively less capital to lose in the event of default. The moral hazard hypothesis predicts that low bank capitalization Granger-causes an increase in loan loss provision.

Each of these four hypotheses would of course also entail a different set of regulatory implications. Whereas the bad luck hypothesis would highlight the need for regulators put an effort into insulating the banking system towards external shocks, the bad management hypothesis as well as the skimping hypothesis would indicate that supervisors should focus their attention towards bankinternal credit-risk management systems. The moral hazard hypothesis would alternatively suggest a close monitoring of banks with comparatively low capitalization levels.

\subsection{Empirical Literature}

We now turn to the findings of the former studies on this issue. The seminal paper is Berger and DeYoung (1997). They investigate the causality between loan quality, cost efficiency and capitalization on a large sample of US commercial banks for the period 1985-1994. Loan quality is proxied by the ratio of non-performing loans to total loans. Cost efficiency is estimated by a stochastic frontier approach to produce an annual efficiency score for each bank. To test Granger causality, the model includes three equations so that each of the three main variables is regressed on its lagged values and on those of both other variables, while other sources of cross-sectional and time variation are controlled for. Each equation is then estimated by O.L.S and the sum of the lagged coefficients of each variable yields information on the causality. The paper finds a negative relationship between cost efficiency and non-performing loans which runs in both directions, corroborating both the bad luck hypothesis and the bad management hypothesis. Among the most efficient banks, exogenous increases in cost efficiency tend to lead to increases in problem loans (support for skimping hypothesis); and among the least-well capitalised banks, exogenous reductions in capital tend to lead to increases in problem loans (support for moral hazard hypothesis).

Williams (2004) presents a robustness test of Berger and DeYoung (1997)'s work on a large sample of European savings banks from 1990 to 1998 . Loan quality is defined as the ratio of loan loss provisions to total loans. This ratio might be less relevant than the ratio of non-performing loans to total loans, as it could be endogenous in the estimations owing to the influence of bank management on provisions. Cost and profit efficiency scores, all measured using the stochastic frontier approach, are alternatively used in the tests. Otherwise the methodology is similar to that of Berger and DeYoung (1997). This study concludes that decreases in cost and profit efficiency tend to be followed by deteriorations in loan quality, in accordance with the bad management hypothesis. In addition, for the most cost efficient European banks, Williams (2004) find strong statistical evidence to reject the skimping behaviour hypothesis. The paper does not find any strong statistical evidence to suggest that European banks are characterised by bad luck; skimping or moral hazard behaviour. The relatively weak statistical associations for European banks could be attributable to the specification of variables that only proxy for those used by Berger and DeYoung.

Rossi et al. (2005) extend Williams (2004)'s work to the case of transition countries. Their analysis is performed on a sample of 278 banks from nine transition countries from 1995 to 2002, using data from Bankscope. They investigate the relationships between loan quality, cost and profit efficiency, and capitalization similarly to both former papers. Loan quality is again defined by the ratio of loan loss provisions to total loans and efficiency scores are estimated by the stochastic frontier approach. The paper concludes in favor of the bad luck hypothesis as reductions in loan quality precede reductions in cost and profit efficiency.

Finally, the paper of Weill et al. (2008) addresses the question of the causality between non-performing loans and cost efficiency in order to examine whether either of these factors is the deep determinant of bank failures. They extend the Granger-causality model developed by Berger and DeYoung (1997) by applying G.M.M dynamic panel estimators on a panel of Czech banks between 1994 and 2005. Their findings support the bad management hypothesis, according to which deteriorations in cost efficiency precede increases in non-performing loans. Thus, banking supervisors should consequently focus on enhanced cost efficiency of banks in order to reduce the likelihood of bank failures in transition countries

Furthermore, they tend to reject the bad luck hypothesis as they do not observe a significant and negative impact of non-performing loans on cost efficiency.

\section{Methodology}

This section develops the methodology adopted to investigate the sense of the causality between loan quality, cost/profit efficiency and capitalization on a sample of Tunisian commercial banks for the period 1989-2006. The first subsection displays the econometric model used to investigate the causality, the second subsection describes the data and variables and the third subsection presents how we estimated cost/profit efficiency.

\subsection{Econometric Modelling of Management Behaviour}

We adopt the Granger causality framework used by Berger and DeYoung (1997) in their study of US banks, which implies that our estimates are a robustness test of the results of the former authors. The different types of management behaviour are predicted by the intertemporal relationships between loan loss provision, efficiency, and capitalisation. 
The structure of Eqs.[1]-[3] shows that each dependent variable is regressed on annual lags of it and the two other variables. For instance, a significant relationship between current and past (lagged) cost efficiency would imply that the latter contains information that improves our prediction of current productive efficiency. In this way the lagged values of the right hand side variables with lags up to time $(t-n)$ Granger cause changes in the dependent variable at time $(t)$.

Eq.[1] tests the bad management hypothesis. A priori bad management predicts a negative relationship between loan loss provision and lagged productive efficiency. A positive relationship between the two variables, however, suggests skimping behaviour. It is expected that the more efficient banks are most likely to engage in skimping behaviour.

Therefore, Eq.[1] tests the moral hazard hypothesis using a sub-sample of thinly capitalized banks. We expect a negative relationship between the loan loss provision and the lagged value of the capitalization variables.

Eq.[2] tests the bad luck hypothesis. We expect an inverse relationship between productive efficiency and lagged loan loss provision.

The bad management, skimping and moral hazard hypothesis are tested using the estimated parameters of Eq.[1] whilst the bad luck hypothesis is tested using the estimated parameters of Eq.[2]. Eq.[3] is included to complete the model, and is not used to test any of the four hypotheses.

$$
\begin{aligned}
& \mathrm{LLP}_{i t}=\mathrm{f}_{1}\left(\mathrm{LLP}_{\mathrm{i} \text { lag }}, \mathrm{EFF}_{\mathrm{i} \text { lag }}, \mathrm{CAP}_{\mathrm{i} \text { lag }}, \mathrm{LTA}_{\mathrm{i} \text { lag }}, \mathrm{D}_{\mathrm{t}}\right)+\varepsilon_{1, \mathrm{it}} \\
& \mathrm{EFF}_{\text {it }}=\mathrm{f}_{2}\left(\mathrm{LLP}_{\mathrm{i} \text { llag }}, \mathrm{EFF}_{\mathrm{i}, \text { lag }}, \mathrm{CAP}_{\mathrm{i}, \text { lag }}, \mathrm{LTA}_{\mathrm{i}, \text { lag }}, \mathrm{D}_{\mathrm{t}}\right)+\varepsilon_{2, \mathrm{it}} \\
& \mathrm{CAP}_{\text {it }}=\mathrm{f}_{3}\left(\mathrm{LLP}_{\mathrm{i}, \text { lag }}, \mathrm{EFF}_{\mathrm{i}, \text { lag }}, \mathrm{CAP}_{\mathrm{i}, \text { lag }}, \mathrm{LTA}_{\mathrm{i}, \text { lag }}, \mathrm{D}_{\mathrm{t}}\right)+\varepsilon_{3, \text { it }}
\end{aligned}
$$

The model outlined in Eqs.[1]-[3] is estimated using a dynamic panel data estimator in order to reflect the panel data structure, i.e., mainly to account for the time dependence of the observations within each bank and account for bank-specific effects in the studied variables. We made use of the Arellano and Bond (1991) dynamic panel data estimator. The estimator removes the bankspecific effects by data first-differencing and uses instruments to carry out the G.M.M estimation. We use equally distributed lags for both specifications, i.e., Eqs.[1][3], which allows for an independent estimation of each equation.

We determine the number of lags using a sequential procedure. Each equation is successively estimated for a number of lags $k$ ranging between 1 and 3 (maximum value determined by the Akaike Information Criterion "A.I.C" and the Schwarz Information Criterion "S.C"). This sequential procedure, which has been supported by an $L R$ test, specifies one lagged periods for each equation.

\subsection{Data and Variables}

Our dataset come from the management reports and the database of the Tunisia's Professional Association for Banks and Financial Institutions (A.P.T.B.E.F). These reports include balance sheets and income statements published by the banks. This study covers the period 19892006, using annual data. The analyzed sample consists of all the commercial banks except for two banks lately created, such as the Tunisian Solidarity Bank (B.T.S) and Arab Banking Corporation (A.B.C) which did not have a regular activity during the period of our study. Moreover, for the sake of statistical homogeneity, we have excluded another small bank: Citibank (C.B) from the field of our study ${ }^{2}$.

We have chosen the deposit banks exclusively for two reasons. On the one hand, the difference between the accounting and financial structures of two categories of the banks (development banks and deposit banks) makes the interpretation of the results difficult. On the other hand, the deposit banks occupy the most significant place in the financing of the Tunisian economy. Indeed, more than $90 \%$ of the saving is collected by the commercial banks and more than $80 \%$ of the loans are granted by these banks. Our final sample comprises observations made on 11 Tunisian commercial banks over 1989-2006 period.

Eqs. [1]-[3] specify the following variables. The ratio of loan loss provision-to-loans $\left(\mathrm{LLP}_{\text {it }}\right)$ is an indicator of asset quality. Two estimates of efficiency are used in this study $\left(\mathrm{EFF}_{\text {it }}\right)$. Following the recommendation of Berger and DeYoung and in addition to estimating cost efficiency, we also estimate alternative profit efficiency ${ }^{3}$.

The ratio of equity-to-total assets is the measure of bank capitalisation and indicates the size of banks' financial cushion for absorbing losses emanating from the loan

\footnotetext{
2 S.T.B, Tunisian Banking Company; B.N.A, National Agricultural Bank; B.H, Bank for Housing ; B.S, Bank of the South; B.I.A.T, Arab International Bank of Tunisia; U.B.C.I, Banking Union for Trade and Industry; U.I.B, International Banking Union; B.T, Bank of Tunisia; A.B, Amen Bank; A.T.B, Arab Tunisian Bank and B.F.T, Franco Tunisian Bank.

${ }^{3}$ We use estimated profit efficiency to re-test for skimping behaviour because skimping behaviour reduces output quality, which affects both costs and revenues. As problem loans increase bank costs rise because, for example, of the need for increased monitoring of borrowers. Revenues, on the other hand, will be lost because of rising problem loans.
} 
portfolio $\left(\mathrm{CAP}_{\text {it }}\right)$.

In order to control for risk and other factors we specify two control variables in each equation. The ratio of loans to assets $\left(\mathrm{LTA}_{\text {it }}\right)$ is a proxy of credit risk. The inclusion of a set of dummy variables $\left(D_{t}\right)$ for each time period inter alia controls for changes in the macroeconomic environment like falling interest rates and regulatory changes such as those emanating from Tunisian financial deregulation, as well as changes in technology.

Table 1 presents the descriptive statistics of the variables used in the Granger causality test after one lagged period. In total there are 187 observations.

Table1. Descriptive statistics for variables in the Granger causality model (1 lag)

\begin{tabular}{llll}
\hline Variable & Observations & Mean & $\begin{array}{l}\text { Standard } \\
\text { Deviation }\end{array}$ \\
\hline LLP & 187 & 0.0129 & 0.0077 \\
CE & 187 & 0.7158 & 0.1246 \\
PE & 187 & 0.8045 & 0.1728 \\
LTA & 187 & 0.8005 & 0.2152 \\
CAP & 187 & 0.0802 & 0.0356 \\
\hline
\end{tabular}

CE: cost efficiency score; PE: profit efficiency score

An interesting feature of our data sample is the little variability of the mean ratio of loan loss provision to loans as measured by the standard deviation, that is to say approximately $0.77 \%$. Whereas there is much greater variation in the ratio of equity to assets (3.56\%) and in a more significant way for the ratio loans to assets $(21.52 \%)$.

The mean level of cost efficiency is $71.58 \%$. That implies that Tunisian banks can, on average, reduce its costs of $39.70 \%$ to be located on the efficient frontier ${ }^{4}$. Our alternative profit efficiency estimates imply that Tunisian banks lose just over $24.3 \%$ of potential profit to inefficiencies.

\subsection{The Measurement of Efficiency}

In modeling banks' cost or profit function, one of the most debated questions in literature is the definition of the inputs and outputs of multi-product financial firms. The discussion concentrates particularly on the role of deposits,

\footnotetext{
${ }^{4}$ The relation between efficiency (Eff) and the inefficiency (Ineff) is: Ineff $=(1-E f f) / E f f$. Thus, a score of efficiency equal to $71.58 \%$ corresponds to a score of inefficiency of $39.70 \%$ and not $28.42 \%$ (for more detail see Berger and Mester, 1997; Isik and Hassan, 2003; Isik, Gunduz and Omran, 2004).
}

considering that they have both input and output characteristics. Empirical literature on banking suggests different approaches to this issue: the most used are the production approach and the intermediation approach. In methodological terms, we are inclined to use the intermediation approach ${ }^{5}$.

In the Tunisian context, the banks use the funds at their disposal to pursue a massive policy of loans. Then, it seems judicious to regard the liability of the Tunisian banks as input rather than output. From this perspective, the intermediation approach would be adopted. The bank is then regarded as a financial intermediary between ultimate lenders and ultimate borrowers. It collects resources from the public and transforms them into long term loans.

For our study and according to the availability of the data, we could retain two outputs and three inputs. The outputs offered by the Tunisian commercial banks are classified in two categories: the Total of Loans (TL) which includes all the types of loans and the Titles Portfolios (TP) which represents the activities of placement and investment considered as services carried out by the bank.

Furthermore, we took as an indicating variable the aggregate output $(\mathrm{Q})$ obtained thanks to the method of aggregation suggested by Benston, Hanweck and Humphrey (1982) which can be presented as follows:

$$
\begin{aligned}
& \mathrm{Q}_{\mathrm{i}}=\frac{\sum_{\mathrm{s}} \mathrm{n}_{\mathrm{si}}}{\sum_{\mathrm{s}} \overline{\mathrm{n}_{\mathrm{S}}}} \overline{\mathrm{Q}} \\
& \text { With } \mathrm{Q}_{\mathrm{i}} \text { : the aggregate output of bank } \mathrm{i} ; \\
& \quad \mathrm{s} \text { : banking services referred to above (TL and } \mathrm{TP}) ; \\
& \quad \mathrm{n}_{\mathrm{si}} \text { : quantity of the output s of bank } \mathrm{i} ;
\end{aligned}
$$

\section{$\bar{Q}$ : a geometric mean of the sum of the different banking outputs} definite as follows:

$$
\overline{\mathrm{Q}}=\prod_{\mathrm{i}}\left[\sum_{\mathrm{S}} \mathrm{n}_{\mathrm{si}}\right]^{1 / \mathrm{m}}
$$

$\mathrm{m}$ : the number of the banks in the sample;

$\overline{\mathrm{n}_{\mathrm{S}}}$ : a geometric mean of the of banking outputs definite as follows:

$$
\overline{n_{\mathrm{s}}}=\prod_{\mathrm{i}}\left[\mathrm{n}_{\mathrm{si}}\right]^{1 / \mathrm{m}}
$$

The outputs quoted above are produced thanks to the combination of the factors of production, namely: the labour factor (L), the physical capital factor (K) and the financial capital factor (F). The labour factor (L) is measured by the number of employees; the physical capital factor $(\mathrm{K})$ is measured by the book value of premises and fixed assets and the financial capital factor $(\mathrm{F})$ is measured by the various forms of deposits. Furthermore, in conformity with most previous studies on baking efficiency, we select the following three input prices: the unit price of

\footnotetext{
${ }^{5}$ Several studies on the efficiency of the banks adopted the intermediation approach (Aly et al., 1990; Berger and Mester, 1997; Chaffai , 1997; Chaffai and Dietsch, 1998; Isik and Hassan , 2003; Allen and Liu , 2007).
} 
labour (PL) calculated by dividing the personnel expenses by the number of employees; the unit price of the physical capital (PK) calculated by dividing the expenditures on plant and equipment (i.e. overhead expenses net of personnel expenses) by the book value of premises and fixed assets; and the unit price of the financial capital (PF) is computed by the total interest expenses of deposits divided by the sum of deposits.

The endogenous variable is defined by the total cost (TC), which includes the whole of the financial and operative costs ${ }^{6}$.

Table 2 presents the descriptive statistics (average, standard deviation, minimum and maximum) of total cost, total profit, the aggregate output, the inputs and their prices.

Table 2. Descriptive statistics of the variables of the translog cost/profit function over 1989-2006 period

\begin{tabular}{|c|c|c|c|c|c|}
\hline Variable & $\begin{array}{l}\text { Observa } \\
\text { tions }\end{array}$ & Average & $\begin{array}{l}\text { Standard } \\
\text { Deviation }\end{array}$ & $\begin{array}{l}\text { Mini } \\
\text { mum }\end{array}$ & $\begin{array}{l}\text { Maximu } \\
\text { m }\end{array}$ \\
\hline$T C^{*}$ & 198 & 90501 & 58370 & 3276 & 246630 \\
\hline$T P R O F^{*}$ & 198 & 111070 & 72665 & 5701 & 324268 \\
\hline$L$ & 198 & 1393 & 826 & 180 & 3154 \\
\hline$K^{*}$ & 198 & 27902 & 21850 & 673 & 101347 \\
\hline$F^{*}$ & 198 & 1237630 & 910448 & 53928 & 3965021 \\
\hline$P L$ & 198 & 15,7903 & 6,8127 & 5,3676 & 34,4047 \\
\hline$P K$ & 198 & 0,8304 & 0,5193 & 0,1698 & 2,9897 \\
\hline$P F$ & 198 & 0,0445 & 0,0170 & 0,0097 & 0,1169 \\
\hline$T L^{*}$ & 198 & 1221445 & 895009 & 43076 & 4013283 \\
\hline$T P^{*}$ & 198 & 140678 & 140316 & 253 & 654960 \\
\hline$Q^{*}$ & 198 & 1389036 & 1028474 & 46737 & 4413806 \\
\hline
\end{tabular}

* In thousands of dinars

Due to the disadvantages of the Cobb-Douglas model ${ }^{7}$, we will use the translogarithmic model in our analysis. The use of the disaggregated translog model, as used in the American studies, involves a number of explanatory variables higher than the size of the Tunisian banking population. For this reason we cannot use this model. So, we will be satisfied with the estimate of the productivity efficiency while supposing that the technology of the Tunisian banks is represented by an aggregate translogarithmic cost function. Thus, we use the following

\footnotetext{
${ }^{6}$ In the case of the alternative profit function, the endogenous variable is defined by the total profit (TPROF), which includes all the interests' incomes and the commissions received by the bank.

${ }^{7}$ Constant return of scale and does not make it possible to obtain a curve of average cost in $U$ form, which is a successive simplification in the reality of the behaviour of the banking cost function.
}

translog specification for the cost function ${ }^{8}$ :

$$
\begin{aligned}
\operatorname{Ln}(\mathrm{TC})_{\mathrm{it}}= & \alpha_{0}+\beta_{\mathrm{Q}} \operatorname{Ln}\left(\mathrm{Q}_{\mathrm{it}}\right)+\frac{1}{2} \beta_{\mathrm{QQ}}\left[\operatorname{Ln}\left(\mathrm{Q}_{\mathrm{it}}\right)\right]^{2}+\sum_{\mathrm{j}} \alpha_{\mathrm{j}} \operatorname{Ln}(\mathrm{Pj})_{\mathrm{it}} \\
& +\sum_{\mathrm{j}} \beta_{\mathrm{jQ}} \operatorname{Ln}(\mathrm{Pj})_{\mathrm{it}} \operatorname{Ln}\left(\mathrm{Q}_{\mathrm{it}}\right)+\frac{1}{2} \sum_{\mathrm{j} \mathrm{k}} \sum_{\mathrm{jk}} \operatorname{Ln}(\mathrm{Pj})_{\mathrm{it}} \operatorname{Ln}(\mathrm{Pk})_{\mathrm{it}}+\mathrm{v}_{\mathrm{it}}+\mathrm{u}_{\mathrm{it}}
\end{aligned}
$$

$\mathrm{i} \in(1 \rightarrow 11):$ Indicate the number of the banks;

$\mathrm{t} \in(1 \rightarrow 18):$ Indicate the years of study

$(1989 \rightarrow 2006)$.

With:

$\mathrm{TC}_{\text {it }}$ : The functions of the cost to estimate bank $\mathrm{i}$ at the year $\mathrm{t}^{9}$.

$Q_{\text {it }}$ : The aggregate output of bank $i$ at the period $t$.

$\mathrm{PL}_{\text {it }}$ : The price of the labour factor of bank $\mathrm{i}$ at the period t.

$\mathrm{PK}_{\text {it }}$ : The price of the physical capital factor of bank $\mathrm{i}$ at the period $t$.

$\mathrm{PF}_{\text {it }}$ : The price of the financial capital factor of bank $\mathrm{i}$ at the period $t$.

$\mathrm{v}_{\text {it }}$ : The random error term is independently and identically distributed according to standard normal distribution, $\mathrm{N}\left(0, \sigma_{\mathrm{V}}^{2}\right)$.

$\mathrm{u}_{\text {it }}$ : The asymmetrical error term measuring the bank inefficiency components.

The restrictions in the form of the linear homogeneity conditions and cost exhaustion are obtained by normalizing total costs/profits, the price of the physical capital and the price of financial capital by the price of labour capital. The symmetry conditions state that: $\beta_{\mathrm{jk}}=\beta_{\mathrm{kj}} \mathrm{j}, \mathrm{k} \in\{\mathrm{L}, \mathrm{K}, \mathrm{F}\}$.

The linear homogeneity restrictions demand that:

\footnotetext{
${ }^{8}$ Some other studies rely on the Fourier Flexible specification to estimate efficiency (e.g. DeYoung and Hasan, 1998; Carbo et al., 2002). Berger and Mester (1997) found that both the translog and the FF function form yielded essentially the same average level and dispersion of measure efficiency, and both ranked the individual banks in almost the same order. Vander Vennet (2002) also finds similar results but reports the ones obtained from the translog model. We therefore use the tranlog specification as in several other recent studies such as Dietsch and Lozano-Vivas (2000) Cavallo and Rossi (2002), Bonin and al. (2005), Carvallo and Kasman (2005), Fries and Taci (2005), Bos and Kool (2006).

${ }^{9} \mathrm{TC}$ is replaced by TPROF when the alternative profit function is estimated and $\mathcal{E}_{\text {it }}=\mathrm{v}_{\text {it }}-\mathrm{u}_{\text {it }}$
} 


$$
\left\{\begin{array}{l}
\sum_{\mathrm{j}} \alpha_{\mathrm{j}}=1 \\
\sum_{\mathrm{j}} \beta_{\mathrm{jk}}=0 \\
\underset{\mathrm{j}}{\sum_{\mathrm{j}} \beta_{\mathrm{Q}}=0}
\end{array} \quad \text { with } \mathrm{j}, \mathrm{k} \in\{\mathrm{L}, \mathrm{K}, \mathrm{F}\} .\right.
$$

The translog cost/profit regressions (4) are estimated using the stochastic frontier approach with the time varying panel model (Battese and Coelli, 1992) which allows the inefficiency term of each bank to vary over time. The model provides maximum likelihood estimates of the following parameters:

The inefficiency term, which varies over time according to the following behaviour $\mathrm{u}_{i \mathrm{t}}=\mathrm{u}_{\mathrm{i}} \mathrm{e}^{-\eta(\mathrm{t}-\mathrm{T})}$. Where $u_{i} \rightarrow N\left(\mu, \sigma_{u}^{2}\right):$ represent the deviation of firm $i$ compared to the efficient frontier; $u_{i t}$ is the inefficiency term of bank $i$ at time $t$ (which is the last period considered) and $\eta$ is a parameter to be estimated (when $\eta$ is bigger then zero the inefficiency term, $u_{i t}$, is decreasing over time; when $\eta$ is smaller then zero $u_{i t}$ is increasing over time; $u_{\text {it }}$ stays steady if $\eta=0$ );

The mean, $\mu$, of the truncation at zero of a normal density distribution; $\mu$ indicates how far firms operate from the efficient frontier. Econometrically this means that if $\mu$ is significantly different from zero we reject the hypothesis that the distribution is half normal truncated and therefore efficiency is not the prevalent behavior of our bank sample.

The parameter $\gamma=\frac{\sigma_{\mathrm{u}}^{2}}{\sigma_{\mathrm{u}}^{2}+\sigma_{\mathrm{V}}^{2}}$ is the ratio between the variance associated to the inefficiency of the bank and total variance: it must varies between 0 and 1 .

The estimated parameters of the cost and profit functions are shown in Tables 7 and 8 in appendix 1. We make no attempt to control for asset quality or risk in the arguments of the cost and profit functions. This is because it is unknown if problem loans are exogenous (due to bad luck) or endogenous (due to bad management or skimping). Arguably, problem loans should be controlled for if they are exogenous and cause lower bank efficiency whereas endogenous problem loans should not be controlled because managerial practice lowers efficiency.

The evolution of the average efficiency scores of the banking environment over 1989-2006 period and the principal characteristics (average, minimum and maximum), are presented in Table 9 in appendix 2.

\section{Empirical Results}

In this section we present the results of our tests to verify whether the correlation across cost/profit efficiency, asset quality and capitalization detected in the previous analysis could be due to the management behaviour. We employ the model proposed by Berger and DeYoung (1997) and used in Williams (2004), based on the Granger causality approach for testing the different management hypothesis (Eqs.[1]-[3]). The three equations of the model were estimated separately using the Arellano-Bond dynamic panel data model.

Tables 3-6 report the regression result of dynamic panel data model. As can be seen below consistency of the estimators in this model is confirmed which implies that the lagged values of the explanatory variables are valid instruments in the regression ${ }^{10}$. For instance the Sargan's over identification test confirms the validity of the instrument variables used in explaining the dependent variables at the $1 \%$ significance level. The dynamic panel data autocorrelation test result also indicates that there is no second order serial correlation of error term in this model specification, which is in line with the theory.

\subsection{Management Behaviour and/or Skimping Behaviour}

Table 3 shows the G.M.M estimates of Granger causality tests in loan loss provision Eq.[1]. A priori an inverse relationship between loan loss provision and lagged cost efficiency indicates bad management whereas a positive relationship suggests skimping behaviour.

The lagged cost efficiency coefficient is found to be significantly positive at the $1 \%$ significance level, which is strong statistical evidence that Tunisian bank managers do not suffer of bad management. This suggests the skimping dominates the bad management behaviour in Tunisian commercial banks. Since according to the skimping behaviour, managers reduce the amount of bank resources that are expended on monitoring and underwriting lending business in order to improve profitability. Consequently, the managers differ, on a later date, the deterioration of loan quality from their bank.

This suggests that cost efficiency Granger-cause an increase in the non performing loans for the strongly efficient banks.

\footnotetext{
${ }^{10}$ See the results displayed in the last lines of Tables 3-6.
} 
Table 3. G.M.M estimates of Granger causality tests in loan loss provision equation [1] using cost efficiency estimates

\begin{tabular}{|c|c|c|}
\hline $\begin{array}{l}\text { Dependent variable } \\
\text { LLP }\end{array}$ & Coefficient & $\mathbf{Z}$ \\
\hline Constant & $\begin{array}{l}-0.0931 \\
(0.0310)\end{array}$ & $-3.00^{* * *}$ \\
\hline $\operatorname{LLP}_{\mathrm{t}-1}$ & $\begin{array}{l}0.4045 \\
(0.1185)\end{array}$ & $3.41^{* * *}$ \\
\hline $\mathrm{CE}_{\mathrm{t}-1}$ & $\begin{array}{l}0.1521 \\
(0.0457)\end{array}$ & $3.33^{* * *}$ \\
\hline $\mathrm{LTA}_{\mathrm{t}-1}$ & $\begin{array}{l}0.0039 \\
(0.0052)\end{array}$ & 0.75 \\
\hline $\mathrm{CAP}_{\mathrm{t}-1}$ & $\begin{array}{l}-0.1233 \\
(0.3068)\end{array}$ & $-4.02^{* * *}$ \\
\hline $\mathrm{D}_{\mathrm{t}-1}$ & $\begin{array}{l}-0.00159 \\
(0.0026)\end{array}$ & -0.62 \\
\hline Number of instruments & 125 & \\
\hline Number of observations & 176 & \\
\hline Number of banks & 11 & \\
\hline $\begin{array}{l}\operatorname{AR}(1)(p-v a l u e) \\
\operatorname{AR}(2)^{a}(p-\text {-value })\end{array}$ & $\begin{array}{l}-1.89(0.05) \\
-0.21(0.83)\end{array}$ & \\
\hline $\operatorname{Sargan}_{\operatorname{Test}^{\mathbf{b}}}\left(\mathrm{p}\right.$-value $\left.>\chi^{2}(119)\right)$ & $6.88(1.00)$ & \\
\hline
\end{tabular}

Standard deviations are in parentheses, *** statistically significant at $1 \%$ level

The regressions are carried out with the dynamic estimator of Arenallo and Bond (1991) who uses the method of the Generalized Moments (G.M.M) of difference with only one stage. The robust asymptotic standard deviations with the heteroscedasticity are in parentheses.

a. The tests of absence of autocorrelation of the residues of second order is AR(2). This statistical test distributed asymptotically according to $\mathrm{N}(0,1)$ under the null hypothesis of no autocorrelation of the residues.

b. The test of Sargan is the test on over identifying restrictions, follows asymptotically $\chi^{2}(n-p)$. Under the null hypothesis of validation of the instruments, with (n-p): the degree of freedom, n: the number of instruments, $\mathrm{p}$ : the number of parameters.

On the recommendation of Berger and DeYoung (1997) we re-test for evidence of either bad management or skimping behaviour using estimated profit efficiency as the efficiency measure instead of cost efficiency. The parameter estimates are shown in Table 4. The results are robust to the change in measured efficiency. Table 4 shows evidence of skimping as the relationship between loan loss provision and lagged profit efficiency.

Table 4. G.M.M estimates of Granger causality tests in loan loss provision equation [1] using profit efficiency estimates

\begin{tabular}{lll}
\hline $\begin{array}{l}\text { Dependent variable } \\
\text { LLP }\end{array}$ & Coefficient & $\mathbf{Z}$ \\
\hline \multirow{2}{*}{ Constant } & -0.1282 & $-2.54^{* * *}$ \\
& $(0.0294)$ & \\
LLP $_{\mathrm{t}-1}$ & 0.4590 & $3.86^{* * *}$ \\
& $(0.1188)$ & \\
PEE $_{\mathrm{t}-1}$ & 0.1634 & $2.73^{* * *}$ \\
& $(0.0598)$ & \\
LTA $_{\mathrm{t}-1}$ & 0.0034 & 0.65 \\
\hline
\end{tabular}

\begin{tabular}{lll}
\hline $\begin{array}{l}\text { Dependent variable } \\
\text { LLP }\end{array}$ & Coefficient & $\mathbf{Z}$ \\
\hline $\mathrm{CAP}_{\mathrm{t}-1}$ & -0.0642 & $-2.50^{* * *}$ \\
& $(0.3068)$ & \\
$\mathrm{D}_{\mathrm{t}-1}$ & 0.00072 & 0.28 \\
Number of instruments & $(0.0026)$ & \\
Number of observations & 125 & \\
Number of banks & 176 & \\
AR(1) (p-value) & 11 & \\
AR(2) ${ }^{\text {(p-value) }}$ & $-1.87(0.06)$ \\
& $0.10(0.92)$ \\
Sargan Test ${ }^{\mathbf{b}}$ (p-value $\left.>\chi^{2}(119)\right)$ & $7.13(1.00)$ \\
\hline
\end{tabular}

Standard deviations are in parentheses, $* * *$ statistically significant at $1 \%$ level

The regressions are carried out with the dynamic estimator of Arenallo and Bond (1991) who uses the method of the Generalized Moments (G.M.M) of difference with only one stage. The robust asymptotic standard deviations with the heteroscedasticity are in parentheses.

a. The tests of absence of autocorrelation of the residues of second order is $\mathrm{AR}(2)$. This statistical test distributed asymptotically according to $\mathrm{N}(0,1)$ under the null hypothesis of no autocorrelation of the residues. b. The test of Sargan is the test on over identifying restrictions, follows asymptotically $\chi^{2}(n-p)$. Under the null hypothesis of validation of the instruments, with (n-p): the degree of freedom, n: the number of instruments, $\mathrm{p}$ : the number of parameters.

\subsection{Bad Luck Behaviour}

Bad luck is modelled using Eq.[2] and it implies that deteriorating asset quality measured as an increase in loan loss provision is exogenous to the influence of management. Thus, an increase in loan loss provision Granger causes a decrease in bank cost efficiency, which suggests that after loans go bad bank management expends additional operating costs in trying to remedy the situation. Bad luck is identified by an inverse relationship between cost efficiency and lagged loan loss provision.

We find strong statistical evidence that increases in loan loss provision Granger causes a decrease in measured cost efficiency, which implies that Tunisian bank management exhibit characteristics of bad luck (see Table 5). The fact that the lagged coefficients of loan loss provision $\left(\mathrm{LLP}_{\mathrm{t}-1}\right)$ turns to be significant with the negative sign is an indication for the presence of the bad luck hypothesis: unexpected and external factors increase loan loss provisions, which reduce cost efficiency.

Moreover, as shown by the results much of the significance of the estimates is explained by the lagged values of the dependent variables, suggesting that obviously the level of the efficiency today are affected by the past level of efficiency. The remaining coefficients including those for the loan loss provisions take on comparatively small values.

The results are not robust for profit efficiency. Table 10 in appendix 3 shows no evidence of bad luck as the relationship between profit efficiency and lagged loan loss provision is positive although statistically weak. 
Table 5. G.M.M estimates of Granger causality tests in cost efficiency Equation [2]

\begin{tabular}{|c|c|c|}
\hline $\begin{array}{l}\text { Dependent variable } \\
\text { CE }\end{array}$ & Coefficient & $\mathbf{Z}$ \\
\hline Constant & $\begin{array}{l}0.0100 \\
(0.00004)\end{array}$ & $225.72^{* * *}$ \\
\hline $\mathrm{CE}_{\mathrm{t}-1}$ & $\begin{array}{l}0.9912 \\
(0.00007)\end{array}$ & $244.83^{* * *}$ \\
\hline $\operatorname{LLP}_{\mathrm{t}-1}$ & $\begin{array}{l}-0.00017 \\
(0.0598)\end{array}$ & $-4.88^{* * *}$ \\
\hline $\mathrm{LTA}_{\mathrm{t}-1}$ & $\begin{array}{l}-0.00006 \\
(9.48 \mathrm{e}-06)\end{array}$ & $-6.66^{* * *}$ \\
\hline $\mathrm{CAP}_{\mathrm{t}-1}$ & $\begin{array}{l}-0.00012 \\
(0.00005)\end{array}$ & $-2.31^{* *}$ \\
\hline$D_{t-1}$ & $\begin{array}{l}-0.00002 \\
(3.40 \mathrm{e}-06)\end{array}$ & $-4.55^{* * *}$ \\
\hline Number of instruments & 45 & \\
\hline Number of observations & 176 & \\
\hline Number of banks & 11 & \\
\hline $\begin{array}{l}\operatorname{AR}(1)(\mathrm{p} \text {-value }) \\
\operatorname{AR}(2)^{\mathrm{a}}(\mathrm{p} \text {-value })\end{array}$ & $\begin{array}{l}2.27(0.02) \\
1.35(0.18)\end{array}$ & \\
\hline Sargan Test $^{\mathbf{b}}\left(\mathrm{p}\right.$-value $\left.>\chi^{2}(39)\right)$ & $3.06(1.00)$ & \\
\hline
\end{tabular}

Standard deviations are in parentheses, $* * *$ statistically significant at $1 \%$ level, ** statistically significant at $5 \%$ level

The regressions are carried out with the dynamic estimator of Arenallo and Bond (1991) who uses the method of the Generalized Moments (G.M.M) of difference with only one stage. The robust asymptotic standard deviations with the heteroscedasticity are in parentheses.

a. The tests of absence of autocorrelation of the residues of second order is $\mathrm{AR}(2)$. This statistical test distributed asymptotically according to $\mathrm{N}(0,1)$ under the null hypothesis of no autocorrelation of the residues.

b. The test of Sargan is the test on over identifying restrictions, follows asymptotically $\chi(n-p)$. Under the null hypothesis of validation of the instruments, with (n-p): the degree of freedom, $n$ : the number of instruments, $p$ : the number of parameters.

\subsection{Moral Hazard Behaviour}

Moral hazard behaviour is tested using Eq.[1]. The moral hazard hypothesis suggests that thinly capitalised banks assume additional portfolio risk, which eventually Granger causes an increase in loan loss provision. A negative relation is expected between loan provision and the lagged value of the capitalisation.

We find strong statistical evidence that increases in bank capitalisation Granger causes a reduction in loan provision, which implies the existence of moral hazard behaviour for the Tunisian commercial banks.

We re-test for evidence that Tunisian bank management engages in moral hazard behaviour using a sub-sample of the thinly capitalised banks, which is defined as those institutions with equity to assets below the sample median in the first lagged year. The parameter estimates of this model are shown in the Table 6 . The re-estimation of Eq. [1] implies the existence of negative and significant relation between loan provision and the lagged value of the capitalisation. So, there is statistical evidence of moral hazard behaviour at thinly capitalised Tunisian banks.

The results are not robust for profit efficiency. Table 11 in appendix 4 shows no evidence of moral hazard as the relationship between loan provision and the lagged value of the capitalisation is negative although statistically weak.

Table 6. G.M.M estimates of Granger causality tests in loan loss provision equation [1] using cost efficiency estimates

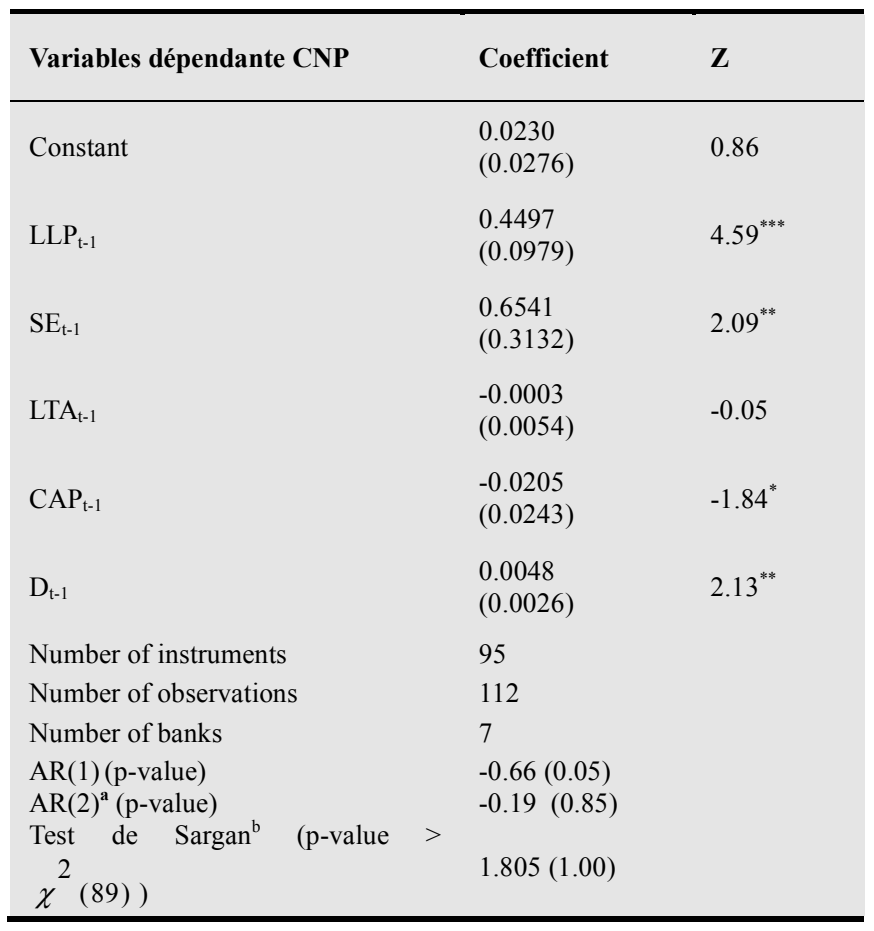

Standard deviations are in parentheses, $* * *$ statistically significant at $1 \%$ level, ** statistically significant at $5 \%$ level, * statistically significant at $10 \%$.

The regressions are carried out with the dynamic estimator of Arenallo and Bond (1991) who uses the method of the Generalized Moments (G.M.M) of difference with only one stage. The robust asymptotic standard deviations with the heteroscedasticity are in parentheses.

CThe sub-sample used to test the moral hazard hypothesis is that of the least capitalised banks, i.e. banks with a ratio of equity to total assets below the median level of 0.0743 .

a. The tests of absence of autocorrelation of the residues of second order is $\mathrm{AR}(2)$. This statistical test distributed asymptotically according to $\mathrm{N}(0,1)$ under the null hypothesis of no autocorrelation of the residues.

b. The test of Sargan is the test on over identifying restrictions, follows asymptotically $\chi^{2}(n-p)$. Under the null hypothesis of validation of the instruments, with (n-p): the degree of freedom, n: the number of instruments, $p$ : the number of parameters.

$* * *$ Least capitalised banks $\bigcirc * * *$

\section{Conclusion}

We use Granger causality estimates to infer different types of management behaviour at Tunisian banks. The inference is based on specific intertemporal relationships between loan loss provision, cost/profit efficiency, and capitalisation.

The results of our analysis suggest that the intertemporal relationships between the loan loss provision and productive efficiency are checked in only one direction. 
Our data support the bad luck hypothesis suggests that high levels of problem loans, generated by external factors such as the environmental conditions, the level of criminality, etc. - cause a decrease in the level of cost efficiency, as an increase in the cost of monitoring and in the other related expenses (e.g. a more prudent administration of the performing loans) will go along with higher provisioning. In addition, we find no evidence of bad management hypothesis for the Tunisian commercial banks. Thus, these banks adopted a skimping behaviour during the period of this study. This makes it possible to draw the conclusion that the deterioration of the bank's asset quality is not the resultant of a bad control of the costs, but following the reduction of the loads of control and monitoring of the borrowers.

Finally, the moral hazard behaviour, according to which the managers of the thinly capitalised banks assume additional portfolio risk, was identified in the Tunisian banking industry.

In terms of regulatory policy implications, this is a signal that bank inefficiency is primarily associated with external shocks beyond the control of management. Regulatory and supervisory rules should therefore focus on reducing banks' exposure to these unforeseen events. This could for instance be done by increasing the diversification of loan portfolios limits in loan concentration, the promoting of mergers with foreign institution or an encouragement of banks toward a low risk profile by lowering the ratio between loan and total assets could be cases in point. Alternatively, higher capitalisation rates are another way to increase banks' shock absorption capacity.

For Tunisia, improvements in the efficiency of the banking systems could have a significant impact on the allocation of financial resources since this sector remains still the most important source of financing private investment of firms, given the underdevelopment of the financial markets.

\section{Appendix}

\section{Appendix 1. Estimated parameters of translog function}

Table 7. Estimated parameters of translog cost function

\begin{tabular}{ccccc}
\hline Variable & & $\begin{array}{c}\text { Coeffic } \\
\text { ient }\end{array}$ & $\begin{array}{c}\text { Standard } \\
\text { deviation }\end{array}$ & $\begin{array}{c}\text { t- } \\
\text { Ratio }\end{array}$ \\
\hline Constant & $\alpha_{0}$ & 0.366 & 0.891 & 0.411 \\
$\mathrm{LN}(\mathrm{Q})$ & $\beta_{\mathrm{Q}}$ & 0.906 & 0.162 & 5.600 \\
$\mathrm{LN}(\mathrm{Q})^{\wedge} 2$ & $\beta_{\mathrm{QQ}}$ & -0.0149 & 0.014 & -1.044 \\
$\mathrm{LN}(\mathrm{PKL})$ & $\alpha_{\mathrm{KL}}$ & 0.0909 & 0.165 & 0.550 \\
$\mathrm{LN}(\mathrm{PFL})$ & $\alpha_{\mathrm{FL}}$ & 0.576 & 0.251 & 2.298 \\
\hline
\end{tabular}

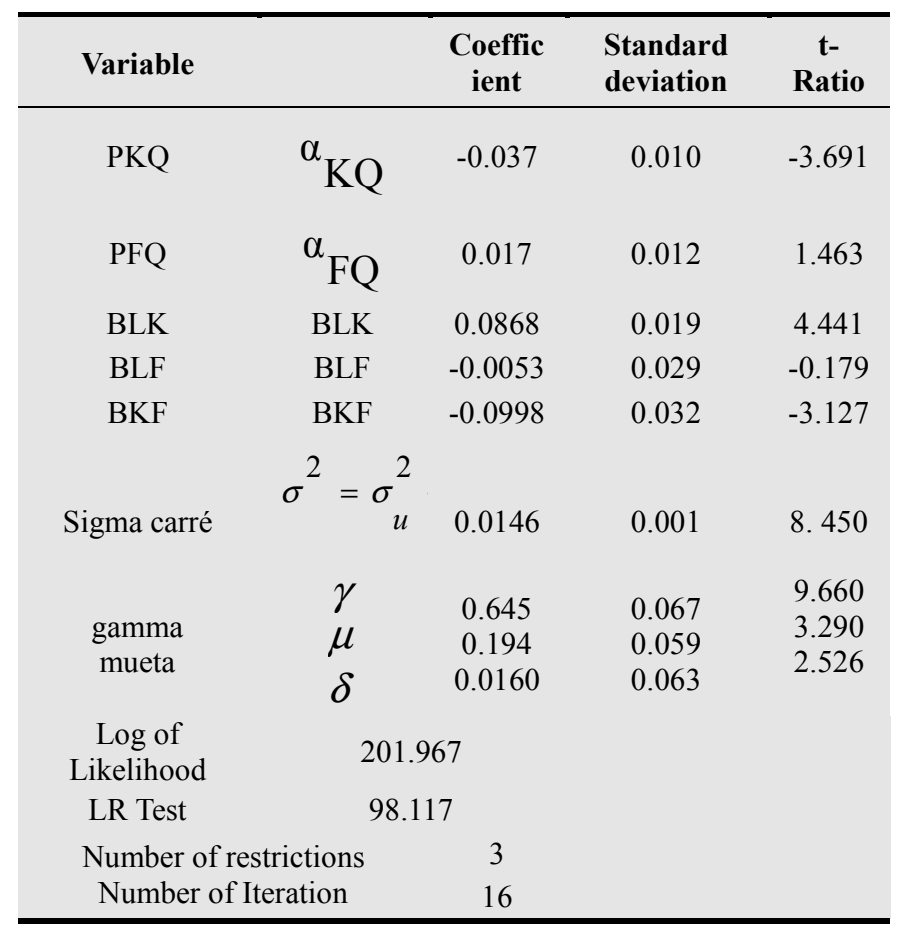

Table 8. Estimated parameters of translog profit function

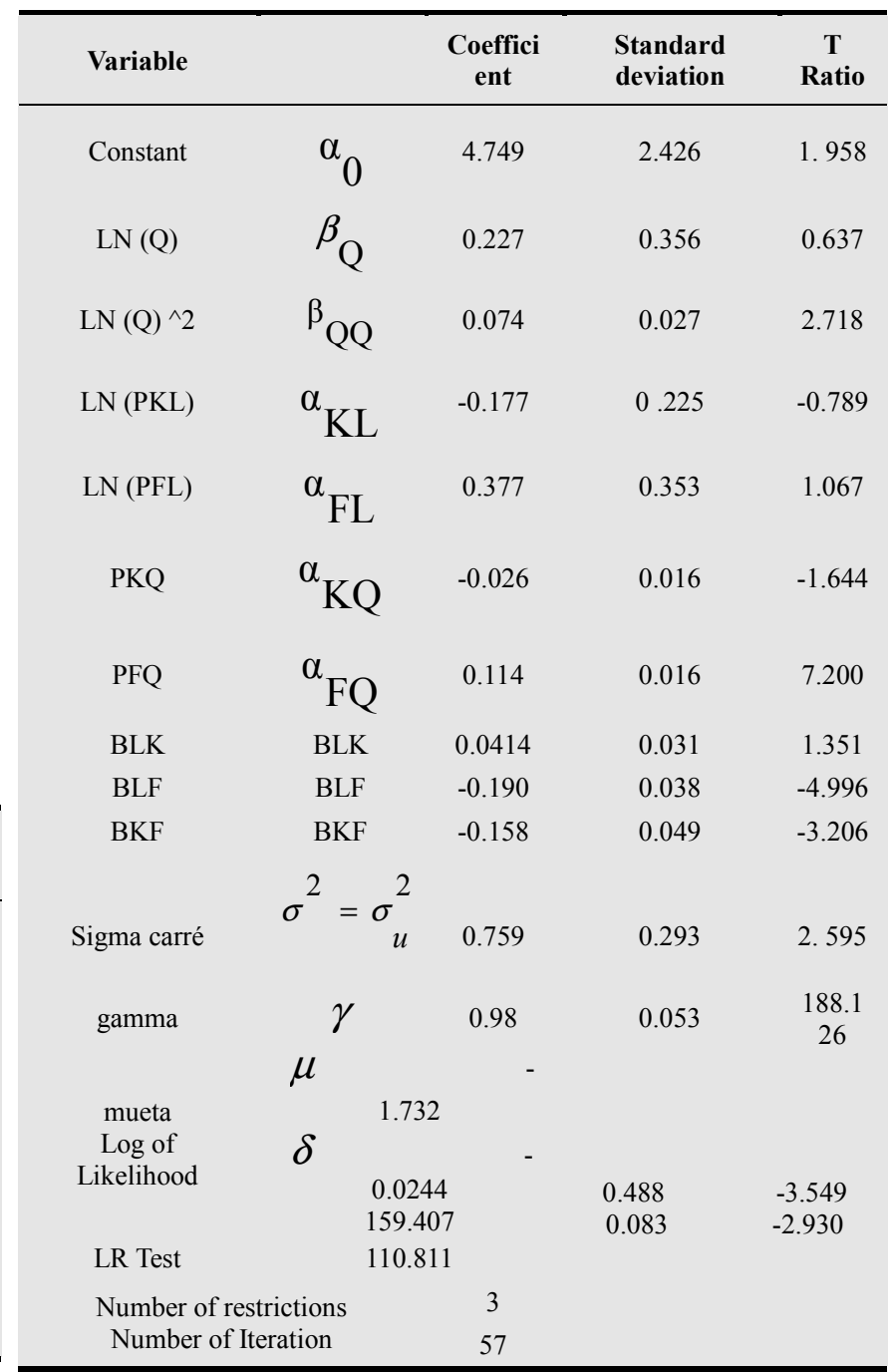




\section{Appendix 2}

Table 9. Means sores of Cost and Profit efficiency over 1989-2006 period

\begin{tabular}{|c|c|c|}
\hline & Cost efficiency & Profit efficiency \\
\hline 1989 & 0.6837 & 0.8352 \\
\hline 1990 & 0.6877 & 0.8318 \\
\hline 1991 & 0.6916 & 0.8285 \\
\hline 1992 & 0.6955 & 0.8250 \\
\hline 1993 & 0.6993 & 0.8216 \\
\hline 1994 & 0.7032 & 0.8352 \\
\hline 1995 & 0.7069 & 0.8318 \\
\hline 1996 & 0.7107 & 0.8285 \\
\hline 1997 & 0.7144 & 0.8250 \\
\hline 1998 & 0.7181 & 0.8216 \\
\hline 1999 & 0.7217 & 0.7996 \\
\hline 2000 & 0.7253 & 0.7957 \\
\hline 2001 & 0.7289 & 0.7918 \\
\hline 2002 & 0.7324 & 0.7879 \\
\hline 2003 & 0.7359 & 0.7839 \\
\hline 2004 & 0.7394 & 0.7798 \\
\hline 2005 & 0.7428 & 0.7757 \\
\hline 2006 & 0.7462 & 0.7715 \\
\hline Mean & 0.7158 & 0.8094 \\
\hline Maximum & 0.7462 & 0.8352 \\
\hline Minimum & 0.6837 & 0.7715 \\
\hline
\end{tabular}

\section{Appendix 3}

Table 10. G.M.M estimates of Granger causality tests in profit efficiency Equation [2]

\begin{tabular}{|c|c|c|}
\hline $\begin{array}{l}\text { Dependent variable } \\
\text { PE }\end{array}$ & Coefficient & $\mathbf{Z}$ \\
\hline Constant & $\begin{array}{l}-0.0107 \\
(0.0003)\end{array}$ & $-31.89^{* * *}$ \\
\hline$P E_{t-1}$ & $\begin{array}{l}1.0086 \\
(0.0004)\end{array}$ & $313.93^{* * *}$ \\
\hline $\operatorname{LLP}_{\mathrm{t}-1}$ & $\begin{array}{l}0.0014 \\
(0.0014)\end{array}$ & 1.00 \\
\hline $\mathrm{LTA}_{\mathrm{t}-1}$ & $\begin{array}{l}0.0005 \\
(0.00008)\end{array}$ & $6.87^{* * *}$ \\
\hline $\mathrm{CAP}_{\mathrm{t}-1}$ & $\begin{array}{l}-0.0059 \\
(0.0003)\end{array}$ & $-21.83^{* * *}$ \\
\hline $\mathrm{D}_{\mathrm{t}-1}$ & $\begin{array}{l}-0.00008 \\
(2.70 \mathrm{e}-05)\end{array}$ & $-3.00^{* * *}$ \\
\hline Number of instruments & 45 & \\
\hline Number of observations & 176 & \\
\hline Number of banks & 11 & \\
\hline $\begin{array}{l}\operatorname{AR}(1)(p-v a l u e) \\
\operatorname{AR}(2)^{\mathrm{a}}(\mathrm{p} \text {-value })\end{array}$ & $\begin{array}{l}1.11(0.26) \\
1.12(0.26)\end{array}$ & \\
\hline Sargan Test ${ }^{\mathbf{b}}\left(\mathrm{p}\right.$-value $\left.>\chi^{2}(39)\right)$ & $0.053(1.00)$ & \\
\hline
\end{tabular}

Standard deviations are in parentheses, $* * *$ statistically significant at $1 \%$ level.

The regressions are carried out with the dynamic estimator of Arenallo and Bond (1991) who uses the method of the Generalized Moments (G.M.M) of difference with only one stage. The robust asymptotic standard deviations with the heteroscedasticity are in parentheses.

(C)The sub-sample used to test the moral hazard hypothesis is that of the least capitalised banks, i.e. banks with a ratio of equity to total assets below the median level of 0.0743 .

a. The tests of absence of autocorrelation of the residues of second order is $\mathrm{AR}(2)$. This statistical test distributed asymptotically according to $\mathrm{N}(0,1)$ under the null hypothesis of no autocorrelation of the residues.

b. The test of Sargan is the test on over identifying restrictions, follows asymptotically $\chi^{2}(n-p)$. Under the null assumption of validation of the instruments, with (n-p): the degree of freedom, $n$ : the number of instruments, $\mathrm{p}$ : the number of parameters.

\section{Appendix 4}

Table 11. G.M.M estimates of Granger causality tests in loan loss provision equation [1] using profit efficiency estimates

\begin{tabular}{|c|c|c|}
\hline Variables dépendante CNP & Coefficient & $\mathbf{Z}$ \\
\hline Constant & $\begin{array}{l}-0.0336 \\
(0.0226)\end{array}$ & -1.49 \\
\hline $\operatorname{LLP}_{\mathrm{t}-1}$ & $\begin{array}{l}0.4501 \\
(0.0967)\end{array}$ & $4.65^{* * *}$ \\
\hline $\mathrm{PE}_{\mathrm{t}-1}$ & $\begin{array}{l}0.0510 \\
(0.0266)\end{array}$ & $1.92^{*}$ \\
\hline LTA $_{\mathrm{t}-1}$ & $\begin{array}{l}0.0030 \\
(0.0055)\end{array}$ & 0.55 \\
\hline $\mathrm{CAP}_{\mathrm{t}-1}$ & $\begin{array}{l}-0.0263 \\
(0.0191)\end{array}$ & -1.38 \\
\hline $\mathrm{D}_{\mathrm{t}-1}$ & $\begin{array}{l}0.0056 \\
(0.0022)\end{array}$ & $2.58^{* * *}$ \\
\hline Number of instruments & 95 & \\
\hline Number of observations & 112 & \\
\hline Number of banks & 7 & \\
\hline $\begin{array}{l}\operatorname{AR}(1)(p \text {-value }) \\
\operatorname{AR}(2)^{\mathbf{a}}(p-\text {-value })\end{array}$ & $\begin{array}{l}-0.49(0.63) \\
-0.11(0.91)\end{array}$ & \\
\hline $\begin{array}{l}\text { Test de } \text { Sargan }^{\mathrm{b}} \quad(\mathrm{p} \text {-value } \\
\left.\chi^{2}(89)\right)\end{array}$ & $3.368(1.00)$ & \\
\hline
\end{tabular}

Standard deviations are in parentheses, $* * *$ statistically significant at $1 \%$ level, * statistically significant at $10 \%$ level.

The regressions are carried out with the dynamic estimator of Arenallo and Bond (1991) who uses the method of the Generalized Moments (G.M.M) of difference with only one stage. The robust asymptotic standard deviations with the heteroscedasticity are in parentheses.

(C) The sub-sample used to test the moral hazard hypothesis is that of the least capitalised banks, i.e. banks with a ratio of equity to total assets below the median level of 0.0743 .

a. The tests of absence of autocorrelation of the residues of second order is $\mathrm{AR}(2)$. This statistical test distributed asymptotically according to $\mathrm{N}(0,1)$ under the null hypothesis of no autocorrelation of the residues.

b. The test of Sargan is the test on over identifying restrictions, follows asymptotically $\chi^{2}(n-p)$. Under the null assumption of validation of the instruments, with (n-p): the degree of freedom, $n$ : the number of instruments, $\mathrm{p}$ : the number of parameters.

$* * *$ Least capitalised banks $@ * * *$ 
JEL Classification: C14, D21, G21, G28.

\section{References}

[1] Allen, J. et Liu, Y. 2007. "Efficiency and economies of scale of large Candian banks" Canadian Journal of Economics, 40 (1): $225-244$.

[2] Altunbas, Y., Evans, L., et Molyneux, P. 2001. "Bank ownership and efficiency." Journal of Money, Credit, and Banking, 33 (4): 926-954.

[3] Aly, Hassan Y., Richard Grabowski, Carl Pasurka, et Nanda Rangan. 1990. "Technical, scale, and allocative efficiecncies in US banking: an empirical investigation." The Review of Economics and Statistics, 72 (2): 211-18.

[4] Arellano M., et Bond, S. 1991. "Some Tests of Specification for Panel Data: Monte Carlo Evidence and an Application to Employment Equations." Review of Economic Studies, 58: 277-297.

[5] Arellano M., et Bover, S. 1995. "Another Look at the Instrumental Variable Estimation of Error-Components Models.” Journal of Econometrics, 68: 29-51.

[6] Berger, A. N., 1995. "The relationship between capital and earnings." Journal of Money, Credit, and Banking, 27: 432456.

[7] Berger, A.N. et Mester, L.J. 1997. "Inside the black box: What explains differences in the efficiencies of financial institutions?" Journal of Banking and Finance, 21: 895-947.

[8] Berger, A.N., DeYoung, R. 1997. "Problem loans and cost efficiency in commercial banks." Journal of Banking and Finance, 21: 849-870.

[9] Berger, A.N., Humphrey, D.B. 1997. "Efficiency of financial institutions: International survey and directions for future research." European Journal of Operational Research, 98 (2): $175-212$.

[10] Bonin, J. P., Hasan, I., et Wachtel, P. 2005. "Bank performance, efficiency and ownership in Transition Countries." Journal of Banking and Finance, 29: 31-53.

[11] Bos, J.W.B. et Kool, C.J.M. 2006. "Bank efficiency: The role of bank strategy and local market conditions." Journal of Banking and Finance, 30: 1953-1974.

[12] Button, K.J., Weyman-Jones, T.G. 1992. "Ownership structure, institutional organisation and measured $\mathrm{X}$ efficiency." The American Economic Review, 82 (2): 439445 .

[13] Cebenoyan, A.S., Cooperman, E.S., Register, C.A., et Hudgins, S.C. 1993. "The relative efficiency of stock versus mutual S\&Ls: A stochastic cost frontier approach.” Journal of Financial Services Research, 7: 151-170.

[14] Chaffai, M.E. 1997. "Estimating input specific technical inefficiency: The case of the Tunisian banking industry." European Journal of Operational Research, 98(2): 314-331.

[15] Chaffai, M.E. et Dietsch, M. 1998. "Productive efficiency performances of Tunisian and Moroccan banks: an econometric analysis using panel data." Paper presented at the ERF Fourth annual conference, Beirut 7-9 September.

[16] DeYoung, R., Sprong, K., et Sullivan, R.J., 2001. "Who's minding the store? Motivating and monitoring hired managers at small closely held commercial banks." Journal of Banking and Finance, 25: 1209-1244.

[17] Dietsch, M. and Lozano-Vivas, A. 2000. "How the environment determines banking efficiency: A comparison between French and Spanish industries." Journal of Banking and Finance, 24: 985-1004

[18] Fries, S., Taci, A. 2005. "Cost efficiency of banks in transition: evidence from 289 banks in 15 post-communist countries." Journal of Banking and Finance, 29: 55-81.

[19] Hasan, I., et Marton, K., 2003. "Development and efficiency of the banking sector in a transitional economy: Hungarian experience." Journal of Banking and Finance, 27: 22492271.

[20] Isik .I, Lokman Gunduz and Mohammed Omran. 2005. "Impacts of Organizational Forms, Stock Performance and Foreign Ownership on Bank Efficiency in Jordan: A Panel Study Approach." Communication à l'Economic Research Forum.

[21] Isik, I. et Hassan, M.K. 2003. "Efficiency, ownership and market structure, corporate control and governance in the Turkish banking industry." Journal of Business Finance and Accounting, 30: 1363-1421.

[22] Mester, L.J. 1996. "A study of banking efficiency taking into account risk-preferences." Journal of Banking and Finance, 20: 1025-1045.

[23] Rossi, S., Schwaiger, M., Winkler, G. 2005. "Managerial behaviour and cost/profit efficiency in the Banking Sectors of Central and Eastern European Countries." Working Paper Nº6, Austrian National Bank, http://www.oenb.at.

[24] Weill, L., 2003. "Banking efficiency in transition economies: the role of foreign ownership." Economics of Transition, 11 (3): $569-592$

[25] Weill, L., 2004. "Is there a lasting gap in Banking efficiency between Eastern and Western European Countries?" LARGE, Université Robert Schuman, Institut d'Etudes Politiques, Strasbourg (mimeo)

[26] Weill, L., et Podpiera, J. 2008. "Bad luck or bad management? Emerging banking market experience." Journal of Financial Stability, 4: 135-148.

[27] Williams, J. 2004. "Determining management behaviour in European Banking." Journal of Banking and Finance, 28: 2427-2460. 